\title{
Cooperation Between a Port and Local Community In Light of Sustainable Development
}

\author{
Boris Marzi ${ }^{1}$, Msc, Klavdij Logožar ${ }^{2}, \mathrm{PhD}$
}

\begin{abstract}
Ports represent the starting and ending point of maritime transport. Representing the meeting points of cargo exchange between maritime and other means of transport, they are an indispensable part of transport-logistic chain. Port also have an important role in development of the surrounding/hosting area from economic, social and environmental aspect. In order to operate successfully, a port must work and act in accordance with sustainability - environmentally, economically and socially responsible. The article presents a case study of sustainable coexistence between an economic subject - cargo port and its natural and social surrounding. Examples of port process and operations improvements in light of sustainable development and harmony with local community will be presented.
\end{abstract}

Keywords: port system, local community, sustainable development

\section{Introduction}

In the globalisation process of the world market, the seaborne trade is of key importance. The port's system is a part of the global maritime market, where exchanges among maritime and land transport operators are taking place. All countries with developed maritime transport pay a particular attention to ports' development, which represents a big power generator in the national and global economy. The fundamental issue is the integration of land and maritime transport, warehousing and goods transhipment. In recent years, the maritime transport has been developing very rapidly, in quantity, technology, and quality. The growth of the maritime transport poses a new challenge: how to transport the goods from one place to another as rapidly and as cheaply as possible. Worldwide, new ports and terminals appear; the existing ones construct new capacities and upgrade their services (Pražnikar et al., 2010).

Ports play a fundamental role in linking sea and land transport. They have become very complex systems due to the variety of cargoes that they handle and their close location to the local communities. For this reason, the proper management of occupational health, safety, security, and environmental issues within ports is crucial (Antão et al., 2016). The environmental issues in ports are very challenging in terms of the need to modify logistic processes and minimize emissions from existing and future port activities (Di Vaio et al., 2019). The environmental issues are primarily associated with vessel and cargo handling operations, industrial activities in ports, port planning and extension initiatives and hinterland accessibility; additionally, public institutions and society in general strongly force ports to perform their social responsibility (Di Vaio and Varriale, 2018). 
Due to the awareness of the importance of a successful sustainable activity, stricter environmental laws and the obtainment of competitive advantages, port systems endeavour to operate more transparently and sustainably (Langley and Capgemini, 2010). Thus, many port's systems communicate with the public about their mode of operating, but in different ways, selecting various criteria and unclear methodology of obtaining the data (Oršič et al., 2017). Due to the importance of a sustainable performance, logistics services, which operate on the principle of the sustainable development, are gaining in importance, whereby the attention is focused on the sustainable and green management of the port's services. Green and sustainable management requires different approach to the strategy and decision-making based on the knowledge and competences, taking into consideration environmental risks of the sustainable development of the port system.

Since several stakeholders are involved in the implementation of the port's activity, the division of responsibilities is of outmost importance, also in the mutual communication and reporting, in order to ensure a sustainable successful port service. This can be achieved through adoption of the ISO 14001 standard by all the stakeholders. In Europe, there is a trend that companies cooperating as providers in the implementation of port's services are interconnected and sustainability oriented. In Italy, a research of factors that boost or hinder the companies to introduce sustainable solutions was carried out (Evangelista 2014), but Marchet et al. (2014) found out that there is a shortage of research and publications on this topic.

\section{Sustainable development goals in the Port of Koper}

The port operators have always been concerned with improving the quality of life in the entire area in which the port is situated. While solving the port development issues, principles of sustainable development and responsible environmental management have to be taken into account. Regarding the development of the Port of Koper, modern sustainable solutions are introduced to the greatest extent possible due to their importance for the local as well as the wider social community. The port pursues sustainable development based on strategic orientations, the adopted Human resource management strategy 2016-2020 as well as environmental strategy and energy policy. In the Port of Koper the relevant indicators were chosen from the field of Ecology, company and economy, which are related to the use of ISO 14000 family of standards and EMAS directive requirements and which contain PDCA (Plan-Do-Check-Act) principles.

In this paper the case of measuring system, reporting and communication of sustainable performance of the port's activity in compliance with PDCA four phases recurrent cycle system of continuous improvements in accordance with ISO 14000 family of standards will be presented. Real data used in the evaluation of the sustainable performance of the company will be shown. The indicators are in accordance with the international standards, verified by external certified auditors, thus the adequate accuracy of mentioned data is guaranteed.

Being aware that the port is an important sustainable development stakeholder whose impacts on the environment and society may be both positive and negative, the Port of Koper has decided to accede to addressing global sustainable development goals in the 
context of comprehensive sustainability reporting. Sustainable Development Goals (SDG) have been adopted by all United Nations member states, their purpose being to pursue the development of the entire society, economy, science and civil society - which will play an important role in attaining the key objectives of the society as a whole by 2030. With its efforts, the Port of Koper addresses 11 sustainable development goals:

\begin{tabular}{|c|c|c|c|c|}
\hline $\begin{array}{l}\text { Sustainable } \\
\text { development } \\
\text { goal }\end{array}$ & $\begin{array}{l}\text { Description of the } \\
\text { Port of Koper's } \\
\text { activity }\end{array}$ & $\begin{array}{l}\text { Links to } \\
\text { essential } \\
\text { content }\end{array}$ & $\begin{array}{l}\text { Indicator } \\
\text { example }\end{array}$ & Objectives \\
\hline $\begin{array}{l}\text { Goal No. 1: } \\
\text { Good Health }\end{array}$ & $\begin{array}{l}\text { Managing the } \\
\text { occupational health and } \\
\text { safety system in } \\
\text { accordance with the } \\
\text { international OHSAS } \\
18001 \text { standard } \\
\text { Targeted training for } \\
\text { safe work of employees } \\
\text { Providing an efficient } \\
\text { system of health } \\
\text { promotion in the } \\
\text { working environment } \\
\text { Managing concentrations } \\
\text { of harmful substances } \\
\text { Execution of analyses, } \\
\text { measurements and load } \\
\text { tests } \\
\text { Reducing the noise level } \\
\text { in the port and noise } \\
\text { from ships } \\
\text { Compliance of outdoor } \\
\text { lighting with legislation } \\
\text { Devising the strategy of } \\
\text { fire protection } \\
\text { development in the port }\end{array}$ & $\begin{array}{l}\text { Providing a safe } \\
\text { working } \\
\text { environment } \\
\text { Assessing respect } \\
\text { for human rights } \\
\text { Noise and light } \\
\text { pollution } \\
\text { Customer health } \\
\text { and safety }\end{array}$ & $\begin{array}{l}\text { The number of } \\
\text { serious injuries at } \\
\text { work } \\
\text { The number of } \\
\text { injuries at work per } \\
\text { million hours } \\
\text { worked } \\
\text { The number of } \\
\text { extraordinary events } \\
\text { per million hours } \\
\text { worked } \\
\text { The number of } \\
\text { patrols } \\
\text { Noise level at night } \\
\text { in the direction of } \\
\text { the city of Koper } \\
\text { Noise level by day } \\
\text { in the direction of } \\
\text { the city of Koper } \\
\text { Percentage of } \\
\text { compliance of } \\
\text { outdoor lighting }\end{array}$ & $\begin{array}{l}\text { A maximum of } 18 \\
\text { injuries at work and } 0 \\
\text { serious injuries per } \\
\text { million hours worked } \\
\text { A maximum of } 25 \\
\text { extraordinary events per } \\
\text { million hours worked } \\
\text { To reduce the noise level } \\
\text { at night in the direction } \\
\text { of the city of Koper to } \\
48 \text { dB } \\
\text { To keep the daily noise } \\
\text { level in front of the } \\
\text { nearest buildings outside } \\
\text { the port area below } 58 \\
\text { dB despite the increase } \\
\text { in throughput and } \\
\text { enlargement of the port } \\
\text { To ensure compliance of } \\
\text { outdoor lighting with the } \\
\text { aim of reducing light } \\
\text { pollution } \\
\text { To ensure an adequate } \\
\text { supply system and a } \\
\text { sufficient quantity of } \\
\text { water for fire } \\
\text { extinguishing } \\
\text { throughout the port area }\end{array}$ \\
\hline $\begin{array}{l}\text { Goal No.2: } \\
\text { Quality } \\
\text { Education }\end{array}$ & $\begin{array}{l}\text { Targeted execution of } \\
\text { functional expert } \\
\text { training } \\
\text { Integrating all employees } \\
\text { in the training } \\
\text { Providing co-financing } \\
\text { to employees for } \\
\text { acquiring a higher level } \\
\text { of education } \\
\text { Improving knowledge } \\
\text { transfer systems } \\
\text { (mentoring, tutoring) } \\
\text { Assessing employee }\end{array}$ & $\begin{array}{l}\text { Educating and } \\
\text { training of } \\
\text { employees } \\
\text { Employee high } \\
\text { work efficiency as } \\
\text { well as satisfaction } \\
\text { and commitment }\end{array}$ & $\begin{array}{l}\text { Average number of } \\
\text { hours of training } \\
\text { per employee }\end{array}$ & $\begin{array}{l}\text { Integrating at least } 80 \% \\
\text { of employees in the } \\
\text { training } \\
\text { Competent employees }\end{array}$ \\
\hline
\end{tabular}




\begin{tabular}{|c|c|c|c|c|}
\hline & competencies & & & \\
\hline $\begin{array}{l}\text { Goal No 3: } \\
\text { Gender } \\
\text { Equality }\end{array}$ & $\begin{array}{l}\text { Consistent } \\
\text { implementation of } \\
\text { provisions of the Code } \\
\text { of Ethics } \\
\text { The Diversity Policy sets } \\
\text { out the target diversity } \\
\text { that is pursued in } \\
\text { relation to gender, age, } \\
\text { education level and other } \\
\text { personal characteristics } \\
\text { Respect for the rights of } \\
\text { employees to freedom of } \\
\text { association, membership } \\
\text { in trade unions and the } \\
\text { workers' council, and } \\
\text { other forms of } \\
\text { association } \\
\text { Consistent } \\
\text { implementation of Rules } \\
\text { on protection of dignity } \\
\text { at work }\end{array}$ & $\begin{array}{l}\text { Diversity, equal } \\
\text { opportunities, and } \\
\text { non- } \\
\text { discrimination }\end{array}$ & $\begin{array}{l}\text { Share of employees } \\
\text { based on gender, } \\
\text { age, education level, } \\
\text { etc. }\end{array}$ & $\begin{array}{l}\begin{array}{l}\text { Absolute non- } \\
\text { discrimination }\end{array} \\
\text { Satisfied employees } \\
\text { Consistent respect of } \\
\text { rights acquired by } \\
\text { employees }\end{array}$ \\
\hline $\begin{array}{l}\text { Goal No. 4: } \\
\text { Clean water } \\
\text { and Sanitation }\end{array}$ & $\begin{array}{l}\text { Reducing drinking water } \\
\text { losses }\end{array}$ & Water use & $\begin{array}{l}\text { Specific } \\
\text { consumption of } \\
\text { water }\end{array}$ & $\begin{array}{l}\text { Maintaining the specific } \\
\text { consumption of water }\end{array}$ \\
\hline $\begin{array}{l}\text { Goal No. 5: } \\
\text { Clean Energy }\end{array}$ & $\begin{array}{l}\text { Introducing energy } \\
\text { efficiency measures } \\
\text { Establishing the energy } \\
\text { management system } \\
\text { Installing the measuring } \\
\text { equipment to acquire the } \\
\text { data on consumption of } \\
\text { energy } \\
\text { Acquiring the } \\
\text { certification for the ISO } \\
\text { 50001 standard - energy } \\
\text { management } \\
\text { Electrifying machinery } \\
\text { and vehicles } \\
\text { Establishing a central } \\
\text { control system for port } \\
\text { lighting } \\
\text { Actively introducing } \\
\text { state-of- the-art and } \\
\text { cleanest technologies to } \\
\text { ensure energy efficiency } \\
\text { Acquiring electricity for } \\
\text { heating of buildings } \\
\text { from renewable energy } \\
\text { sources }\end{array}$ & $\begin{array}{l}\text { Energy efficiency } \\
\text { Commitment to } \\
\text { sustainable } \\
\text { development }\end{array}$ & $\begin{array}{l}\text { Specific fuel } \\
\text { consumption } \\
\text { Specific electricity } \\
\text { consumption }\end{array}$ & $\begin{array}{l}\text { Maintaining the specific } \\
\text { consumption of energy } \\
\text { despite the increase in } \\
\text { throughput and storage } \\
\text { capacities - motor fuel } \\
\text { and electricity }\end{array}$ \\
\hline Goal No. 6: & Strategic orientations & Stability and & Financial ratios & Realising development \\
\hline
\end{tabular}




\begin{tabular}{|c|c|c|c|c|}
\hline $\begin{array}{l}\text { Decent Work } \\
\text { and Economic } \\
\text { Growth }\end{array}$ & $\begin{array}{l}\text { aimed at the long-term } \\
\text { business stability } \\
\text { Acquiring and } \\
\text { maintaining the best } \\
\text { staff } \\
\text { Achieving the culture of } \\
\text { high performance and } \\
\text { excellent management } \\
\text { Executing management } \\
\text { by objectives } \\
\text { Ensuring customer } \\
\text { satisfaction and } \\
\text { commitment } \\
\text { Implementing the } \\
\text { system of human } \\
\text { resource potentials and } \\
\text { successors } \\
\text { New employee hires } \\
\text { based on the principle of } \\
\text { "competent staff - key } \\
\text { positions" } \\
\text { Managing the effective } \\
\text { employee working time } \\
\text { optimally }\end{array}$ & $\begin{array}{l}\text { business } \\
\text { performance } \\
\text { Indirect economic } \\
\text { impacts } \\
\text { Importance of } \\
\text { employment and } \\
\text { concern for the } \\
\text { employees }\end{array}$ & $\begin{array}{l}\text { Net sales } \\
\text { Share of annual } \\
\text { interviews } \\
\text { implemented } \\
\text { Assessment of } \\
\text { employee } \\
\text { satisfaction and } \\
\text { commitment } \\
\text { Share of suitable } \\
\text { managers } \\
\text { (management } \\
\text { competency } \\
\text { assessment based } \\
\text { on the } 360 \text { degree } \\
\text { method) } \\
\text { Share of unused } \\
\text { compensatory and } \\
\text { balance working } \\
\text { hours }\end{array}$ & 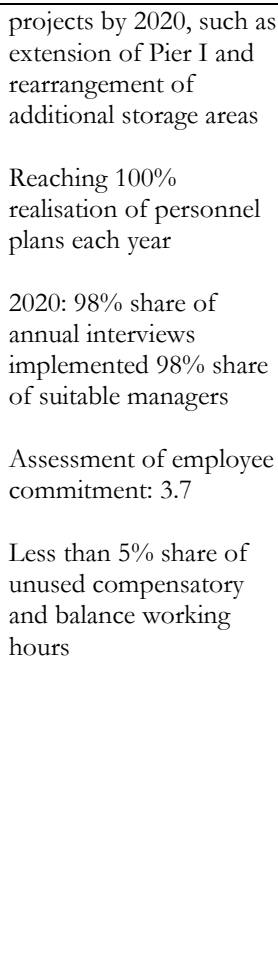 \\
\hline $\begin{array}{l}\text { Goal No. 7: } \\
\text { Industry, } \\
\text { Innovation and } \\
\text { Infrastructure }\end{array}$ & $\begin{array}{l}\text { Creating integrated } \\
\text { transport solutions by } \\
\text { combining various links } \\
\text { of the logistics chain } \\
\text { Stimulating employee } \\
\text { creativity and making } \\
\text { innovative activity part } \\
\text { of the Company's } \\
\text { strategic orientation } \\
\text { Providing new } \\
\text { infrastructure capacities }\end{array}$ & $\begin{array}{l}\text { Stability and } \\
\text { business } \\
\text { performance } \\
\text { Indirect economic } \\
\text { impacts } \\
\text { Stakeholder } \\
\text { engagement }\end{array}$ & $\begin{array}{l}\text { Number of } \\
\text { inspection and } \\
\text { internal measures in } \\
\text { land development } \\
\text { Share of introduced } \\
\text { improvements } \\
\text { Strategic } \\
\text { programme }\end{array}$ & $\begin{array}{l}\text { No inspection and } \\
\text { internal measures in land } \\
\text { development } \\
40 \% \text { of improvements } \\
\text { introduced annually to } \\
\text { the organizational unit } \\
\text { Acquiring new storage } \\
\text { areas } \\
\text { Establishing additional } \\
\text { berths } \\
\text { Improving road access } \\
\text { Establishing new railway } \\
\text { capacities }\end{array}$ \\
\hline $\begin{array}{l}\text { Goal No. 8: } \\
\text { Climate action }\end{array}$ & $\begin{array}{l}\text { Modernising equipment } \\
\text { and dust reducing } \\
\text { systems }\end{array}$ & $\begin{array}{l}\text { Climatic factors } \\
\text { and air quality }\end{array}$ & $\begin{array}{l}\text { Concentration of } \\
\text { particulate } \\
\text { emissions }\end{array}$ & $\begin{array}{l}\text { Maintaining PM10 } \\
\text { particulate emissions (up } \\
\text { to } 10 \mu \mathrm{m} \text { ) in the entire } \\
\text { port area under } 30 \\
\mu \mathrm{g} / \mathrm{m}^{3}\end{array}$ \\
\hline $\begin{array}{l}\text { Goal No. 9: } \\
\text { Life below } \\
\text { water }\end{array}$ & $\begin{array}{l}\text { Establishing adequate } \\
\text { control system over the } \\
\text { entire aquatorium } \\
\text { Alternative solutions for } \\
\text { the handling of marine } \\
\text { sediments }\end{array}$ & $\begin{array}{l}\text { Quality of the sea, } \\
\text { deepening of } \\
\text { seabed and } \\
\text { management of } \\
\text { marine sediments } \\
\text { Biodiversity }\end{array}$ & $\begin{array}{l}\text { Number of sea } \\
\text { pollution instances } \\
\text { outside the Port } \\
\text { aquatorium }\end{array}$ & $\begin{array}{l}\text { Preventing sea pollution } \\
\text { entirely }\end{array}$ \\
\hline
\end{tabular}




\begin{tabular}{|c|c|c|c|c|}
\hline $\begin{array}{l}\text { Goal No. 10: } \\
\text { Life on land }\end{array}$ & $\begin{array}{l}\text { Upgrading waste } \\
\text { management systems } \\
\text { and equipment } \\
\text { Reducing the impact of } \\
\text { potentially contaminated } \\
\text { precipitation water, } \\
\text { process and waste water } \\
\text { by upgrading treatment } \\
\text { plants }\end{array}$ & $\begin{array}{l}\text { Use of land, water } \\
\text { and the formation } \\
\text { of waste water } \\
\text { Waste } \\
\text { management }\end{array}$ & $\begin{array}{l}\text { Maintaining the } \\
\text { share of waste } \\
\text { collected separately }\end{array}$ & $\begin{array}{l}\text { Maintaining the } \\
\text { percentage of waste } \\
\text { collected separately } \\
\text { (excluding ship- } \\
\text { generated waste) above } \\
89 \%\end{array}$ \\
\hline $\begin{array}{l}\text { Goal No. 11: } \\
\text { Peace, justice } \\
\text { and strong } \\
\text { institution }\end{array}$ & $\begin{array}{l}\text { Respect for the } \\
\text { principles of the rule of } \\
\text { law and measures to } \\
\text { prevent corruption and } \\
\text { bribery }\end{array}$ & $\begin{array}{l}\text { Respect for } \\
\text { human rights } \\
\text { Corporate } \\
\text { integrity } \\
\text { Reputation of the } \\
\text { Port of Koper } \\
\text { Operations } \\
\text { compliance } \\
\text { Operational } \\
\text { transparency } \\
\text { Ensuring } \\
\text { customer privacy }\end{array}$ & $\begin{array}{l}\text { Number of } \\
\text { corruption } \\
\text { cases }\end{array}$ & $\begin{array}{l}\text { Maintaining the number } \\
\text { of corruption cases at } 0 \\
\text { Implementing corporate } \\
\text { integrity training }\end{array}$ \\
\hline
\end{tabular}

\section{Methodology for determining materiality}

In its Sustainability Report, the Port of Koper follows the principles of materiality, stakeholder engagement and integrity. According to the materiality principle, the report should reflect significant environmental, economic and social impacts of the organization. In addition, it should include the contents that influence stakeholders' decisions significantly. Port's materiality analysis is therefore based on steps that are presented below.

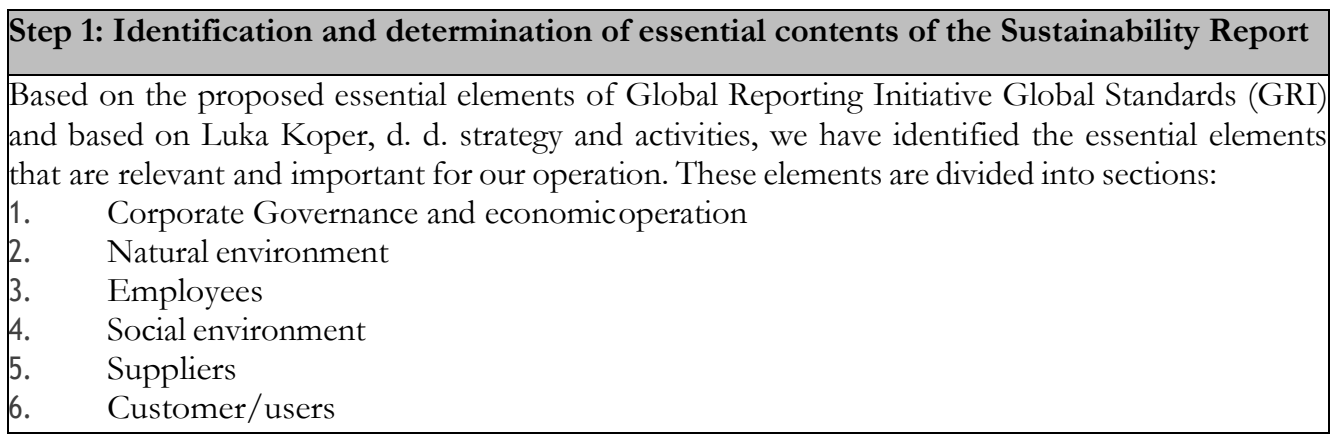

\section{Step 2: Determination of importance by the Company}

Importance as determined by the Company is shown on the horizontal axis of the importance graph, elements ranked in importance from right to left. Importance of identified essential elements has been assessed by the Management Board and members of the project team.

\section{Step 3: Determination of importance by stakeholders}


Importance as determined by stakeholders is shown on the vertical axis of the importance graph, elements ranked in importance from the top down. Stakeholders' assessment was obtained using a questionnaire sent out to key stakeholders. 45 questionnaires were completed. The stakeholders included as well as their expectations can be seen in the table stakeholder engagement, their expectations and needs.

\section{Step 4: Determination of materiality}

The materiality matrix was made based on the answers received. The synergy between the objectives and interests of the Company and stakeholders can be seen in the matrix. We will continue to strengthen the areas, which show related interest, and to bring objectives close together in areas of dissent. The selected essential elements and disclosures of the Sustainability Report are evident from the GRI index, and the conceptual design of this Sustainability Report is based on established materiality.

\section{Stakeholder engagement, their expectations and needs}

Stakeholders of the Port of Koper are defined and recognized in the Policy of Managing. Shareholders can exercise their management rights at the General Meeting of Shareholders. Competencies of the General Meeting and other directly related matters are determined in the Companies Act, Articles of Association of the company, and Rules of Procedure on the Work of the General Meeting of Shareholders.

Customers dictate constant adaptation and introduction of changes and improvements in the Company's operation. Customer satisfaction is the basic guideline of all employees. From the first contact with customers and performing services for them to settling any potential claims, we have to be aware that the very customer satisfaction provides our efforts with meaning and serves as the basis for implementing the vision and mission of the Port of Koper. Satisfaction of Port customers is monitored regularly. Customers are endured top quality services, quick response to the demand and effective communication and other necessary support. The existing model of governing the port serves as the basis for equal treatment of all customers.

Port community participates in changing the functioning of the port system as a whole. Port community is an informal association of all the interested parties whose business activity is directly related to provision of port services. It includes customers forwarding agencies, agents and carriers joining in professional organisations - as well as representatives of controlling firms and inspection authorities, and state agencies, all of them forming expectations towards the Port, aiming at operations being as coordinated as possible at the entry or exit point, which is the actual position of the port area in the entire logistic chain. The Port responds to mentioned demands by coordinating them and communicating with the interested stakeholders.

The Company's performance and the reputation of the Port are also related to the work of suppliers: efforts of all business partners being involved in the operation of the port system and in achieving its operational goals as suppliers of required products or services are therefore highly respected and valued. Employees are encouraged to excellent performance, and are awarded if successful. The partnership employer-employee culture is built on affiliation, cooperation, creativity, respect and responsibility of each individual. A great deal of attention is devoted to internal communication as the foundation of a 
comprehensive communication network. Employees are informed about news, internal acts and other information by e-mails and notice board notifications, the Port Bulletin monthly internal paper and via intranet. Employees who have no computer access, can access the information using information terminals in the management premises. Special attention is also being paid to direct communication between employees in terms of working and operational meetings, quality teams, coordinations, annual interviews of managers with their workers, conferences and other forms of teamwork. Employees are encouraged to constant capacity building. Based on development plans, the career development and critical competencies of each employee are defined in accordance with long-term development needs of the Company.

Commitment to sustainable development is one of the fundamental strategic guidelines. It focuses particularly on establishing and maintaining partnerships with the local community and wider social environment. This at the same time ensures successful development of employees and strong support of the social environment, while also building on the care for the natural environment. Sponsorship and donations are intended to support education, sports, culture and humanitarian projects. Once a year, "the port opens its door widely" on the occasion of the Port Day for visitors from the local and wider environment to view the port, piers, lifts, devices, as well as witness throughput and other activities.

Public authorities: The Government is aware of the immense importance of the Port as the only Slovenian port to the economy as a whole. In 2018, the Company was granted the concession for the provision of port services, management, development and regular maintenance of port infrastructure in the area of the port of Koper. The duration of the concession is 35 years, as laid down in the Maritime Code. The concession fee also includes the water right, water charges and other duties related to the use of the sea. Investments in port infrastructure are performed by the concession holder in agreement with the Republic of Slovenia, and based on a valid five-year port development programme. Concession provider and holder have divided among themselves port management, governance and operation, and agreed on ways of coordinated action to attain the concession objectives in the interests of both parties. It is a commitment and objective of both contracting parties to ensure port openness. It is a commitment to provide services to anybody interested and meeting the conditions in accordance with the principles of the European acquis. The Company's objective is for the Port to become the primary and best port for the countries of Eastern and Central Europe.

The media: The public limited company is open to the general public. The media are responded to their questions in due time and promptly informed of the Company's performance and innovations. Information is also published on the Company's website www.luka-kp.si/eng/, and on its sustainability portal www.zivetispristaniscem.si. Themedia also receive press releases, and invitations to attend press conferences and important business events and visits.

From the range of stakeholders with whom the Port cooperates and develops sustainable relations and who are defined in the Policy of Managing, and in the framework of individual business processes of the Company, we have identified key stakeholders 
based on strategic guidelines, and defined their expectations and ways of involvement in the operation of the Port.

\section{Materiality matrix}

Open relations with stakeholders are of utmost importance to link the goals of sustainable development with social responsibility. Since interests and objectives of individual stakeholders differ, it is important to obtain stakeholders' feedback regarding their expectations from individual companies or groups. The Port has therefore identified the key topics of sustainable development and assessed their importance for the Port operator and for key stakeholders. Based on both aspects, we have devised the matrix of material issues for the company as presented below.

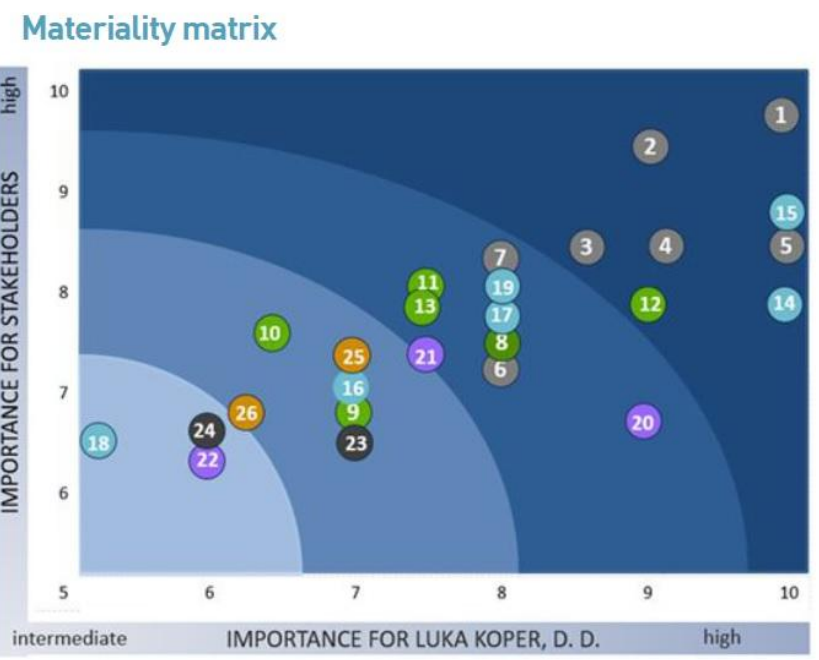

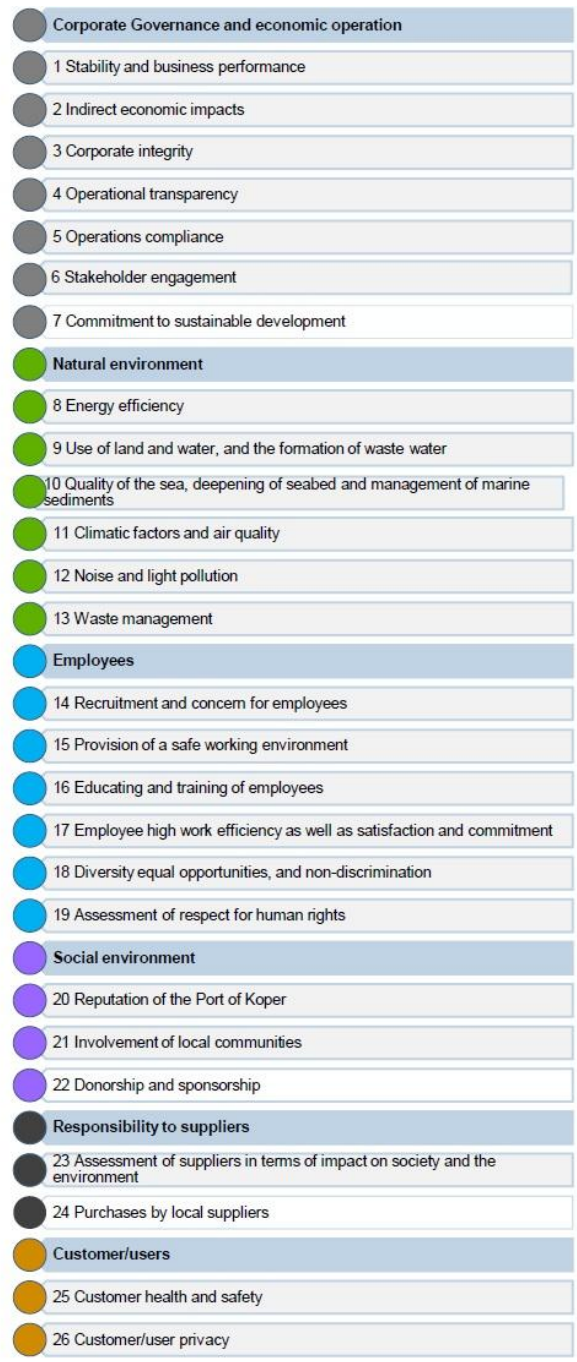




\section{Conclusion}

The development strategy of the Port of Koper is indicated in the activities and measures described in the paper. The port of Koper is fully aware of its significance in relation to the natural and social environment in which it operates; consequently, it maintains a responsible approach towards such issues in its business and development.

\section{References}

Antão, P., Calderon, M., Puig, M., Michail, A., Wooldridge, C. and Darbra, R.M. (2016), "Identification of Occupational Health, Safety, Security (OHSS) and Environmental Performance Indicators in port areas", Safety Science, Vol. 85, pp. 266-275.

Di Vaio, A. and Varriale, L. (2018), "Management Innovation for Environmental Sustainability in Seaports: Managerial Accounting Instruments and Training for Competitive Green Ports beyond the Regulations", Sustainability, Vol. 50, No. 3, 783.

Di Vaio, A., Varriale, L. and Trujillo, L. (2019), "Management Control Systems in port waste management: Evidence from Italy”, Utilities Policy, Vol. 56, pp. 127-135.

Evangelista, P.S. (2014), "Green supply chain initiatives in transport and logistics service industry: an exploratory case study analysis”, Research in Transportation Business \& Management, Vol. 12, pp. 63-72.

Langley, C.J. and Capgemini. (2010). Fifteenth Annual Third-Party Logistics Study.

Likon, M., Grbec, M., Pučko, M., Sedmak Časar, K. and Marzi, B. (2010), "Postopek za energetsko in tehnološko oskrbo pristanišč z izrabo notranjih pristaniških virov", Patent No. SI 22972, Ljubljana: The Slovenian Intellectual Property Office.

Marchet G., Melacini, M. and Perotti, S. (2014), "Environmental sustainability in logistics and freight transportation: A literature review and research agenda", Journal of Manufacturing Technology Management, Vol. 25, No. 6, pp. 775-811.

Marzi, B. and Logožar, K. (2005), "Environmental management system of the Port of Koper regarding "best practices" in EU ports", In: Transportation in science and practice: conference abstracts, 9th International Conference on Traffic Science - ICTS 2005, Portorož: Faculty of Maritime Studies and Transport, pp. 40.

Marzi, B., Zuin, S., Radonjič, G. and Logožar, K. (2013), "Applying the life cycle thinking to sea ports: the case of a Slovenian commercial port", In: Orosa García, J.A. (Ed.). Ships and shipbuilding: types, design considerations and environmental impact, New York: Nova Science Publishers, pp. 205218.

Oršič, J., Tajnik, T., Rosi, B. and Jereb, B. (2017), "Merjenje trajnostne uspešnosti pri izvajalcih logističnih storitev", Uporabna informatika, Vol. 25, No. 2, pp. 79-92.

Pražnikar, J., Marzi, B., Pisanski, T. and Plestenjak, B. (2010), "Izboljšava modela notranjega transporta vozil v Luki Koper”, In: Zbornik referatov, 10. slovenski kongres o cestah in prometu, Ljubljana: DRC - Družba za raziskave v cestni in prometni stroki Slovenije, pp. 273-278.

Port of Koper. (2019), Sustainability Report 2018, Koper: Port of Koper.

Radonjič, G., Fece, V. and Marzi, B. (2014), "Opportunities and obstacles of using LCA within the environmental management system: examples of companies in Slovenia", In: Proceedings, Indian Conference on Life Cycle Management, ILCM 2014, New Delhi: Federation of Indian Chambers of Commerce and Industry, pp. 25-26.

Zuin, S., Radonjič, G., Logožar, K., Belac, E. and Marzi, B. (2009), "Life cycle assessment of ship-generated waste management of Luka Koper”, Waste management, Vol. 29, No. 12, pp. 3036-3046. 